\title{
Synthesis and Optical Power Limiting Properties of Heteroleptic $\mathrm{Mo}_{3} \mathrm{~S}_{7}$ Clusters
}

David Recatalá, ${ }^{\mathrm{a}}$ Rosa Llusar, , a Adam Barlow, ${ }^{\mathrm{b}}$ Genmiao Wang, ${ }^{\mathrm{b}}$ Marek Samoc, ${ }^{\mathrm{c}}$ Mark

G. Humphrey ${ }^{\mathrm{b}}$ and Artem L. Gushchin ${ }^{\mathrm{a}, \mathrm{d}, \mathrm{e}}$

${ }^{a}$ Departament de Química Física i Analítica, Universitat Jaume I, Av. Sos Baynat s/n, 12071 Castelló, Spain

${ }^{\mathrm{b}}$ Research School of Chemistry, Australian National University, Canberra, ACT 2601, Australia

c Advanced Materials Engineering and Modeling Group, Faculty of Chemistry, Wroclaw University of Technology, 50-370 Wroclaw, Poland

${ }^{d}$ Nikolaev Institute of Inorganic Chemistry, Siberian Branch of the Russian Academy of Sciences, 630090 Novosibirsk, Russia

${ }^{\text {e }}$ Novosibirsk State University, 630090 Novosibirsk, Russia

AUTHOR EMAIL ADDRESS: * author for correspondence: rosa.llusar@uji.es TITLE RUNNING HEAD:

\section{CORRESPONDING AUTHOR FOOTNOTE}

a Dept. de Química Física i Analítica, Universitat Jaume I, Av. Sos Baynat s/n, 12071 Castelló, Spain: E-mail: rosa.llusar@uji.es; Tel: +34 964728086; Fax: +34 964728066; Homepage: http://www.grupo-rllusar.uji.es 


\section{Abstract}

Substitution of the halide ligands in $\left(\mathrm{Bu}_{4} \mathrm{~N}\right)_{2}\left[\mathrm{Mo}_{3} \mathrm{~S}_{7} \mathrm{X}_{6}\right](\mathrm{X}=\mathrm{Cl}, \mathrm{Br})$ by diimine ligands, such as 4,4'-dimethyl-2,2'-bipyridine (dmbpy), 2,2'-bipyridine (bpy) and 1,10phenanthroline (phen), affords the neutral heteroleptic clusters $\mathrm{Mo}_{3} \mathrm{~S}_{7} \mathrm{Cl}_{4}(\mathrm{dmbpy})$ (1), $\mathrm{Mo}_{3} \mathrm{~S}_{7} \mathrm{Br}_{4}\left(\mathrm{dmbpy}\right.$ ) (2), $\mathrm{Mo}_{3} \mathrm{~S}_{7} \mathrm{Br}_{4}$ (bpy) (3), and $\mathrm{Mo}_{3} \mathrm{~S}_{7} \mathrm{Br}_{4}$ (phen) (4). Further substitution of the halide ligands in $\mathrm{Mo}_{3} \mathrm{~S}_{7} \mathrm{Br}_{4}$ (diimine) clusters by dmit (1,3-dithiole-2-thione-4,5dithiolate) allows the preparation of the mixed diimine-dithiolene neutral cluster complexes $\mathrm{Mo}_{3} \mathrm{~S}_{7}(\mathrm{dnbpy})(\mathrm{dmit})_{2} \quad(\mathbf{5}, \quad$ dnbpy $=$ 4,4'-dinonyl-2,2'-bipyridine $)$, $\mathrm{Mo}_{3} \mathrm{~S}_{7}(\mathrm{dcmbpy})(\mathrm{dmit})_{2}$ (6, dcmbpy = 4,4'-dimethoxycarbonyl-2,2'-bipyridine), and $\mathrm{Mo}_{3} \mathrm{~S}_{7}(\mathrm{dcbpy})(\mathrm{dmit})_{2}$ (7, dcbpy = 2,2'-bipyridine-4,4'-dicarboxylic acid). The optical limiting properties of complexes $\mathbf{1}$ - $\mathbf{7}$ have been assessed by the open-aperture Z-scan technique at $570 \mathrm{~nm}$, employing a nanosecond optical parametric oscillator. In order to investigate the effect of increasing the $\pi$-system, complexes $\mathbf{1}-\mathbf{4}$, with general formula $\mathrm{Mo}_{3} \mathrm{~S}_{7} \mathrm{X}_{4}$ (diimine), $(\mathrm{X}=\mathrm{Cl}, \mathrm{Br})$, were compared to clusters $\mathbf{5}-\mathbf{7}$, containing the dmit ligand. The influence of the metal content on the optical power limiting properties was also investigated by comparing the trinuclear series of complexes prepared herein with the bis(dithiolene) dinuclear cluster $\left(\mathrm{Et}_{4} \mathrm{~N}\right)_{2}\left[\mathrm{Mo}_{2} \mathrm{O}_{2} \mathrm{~S}_{2}\left(\mathrm{BPyDTS}_{2}\right)_{2}\right]$, which has been recently prepared by our group. All trinuclear clusters $\mathbf{1}-\mathbf{7}$ are efficient optical limiters $\left(\sigma_{\text {eff }}>\sigma_{0}\right)$ with threshold limiting fluence $\mathrm{F}_{15 \%}$ decreasing on proceeding from dinuclear to trinuclear clusters and, generally, on extending the $\pi$-system.

\section{Introduction}

Inorganic materials have been widely used in optics and electronics for many years. With the development of optoelectronics and photonics, the discovery of compounds able to meet the demands of technology has become even more important. In this context, the 
search for materials with improved third-order nonlinear optical (NLO) properties, which include the phenomena of nonlinear refraction and nonlinear absorption, is of utmost importance. Optimizing such materials will permit further developments in a number of photonic technologies. One such application where the existing materials are still lacking the appropriate performance is optical limiting (power limiting). ${ }^{1}$ Optical limiting is a physical phenomenon that involves clamping the optical power transmitted through a material when the incident light intensity increases, which corresponds to the material transmittance decreasing at higher intensities. Power limiting devices based on a variety of materials such as, for example, organic dyes, polymers, inorganic semiconductors, and carbon-based systems like carbon nanotubes or fullerenes have been suggested. A large number of coordination and organometallic molecular complexes that may be useful as NLO materials in photonics have also been reported. ${ }^{2}$ Less attention has been devoted to inorganic clusters. This is mainly due to two reasons: on the one hand, their (usually) deep color makes them unsuitable for NLO applications necessitating transparency in the visible region, and on the other hand, their frequent instability in the presence of high intensity radiation prohibits applications involving lasers. ${ }^{3}$ However, the past two decades have witnessed significant progress in the field since a series of cubane-like heterobimetallic molybdenum and tungsten cluster sulfides were found to be superior optical limiters to fullerene, $\mathrm{C}_{60} .{ }^{4-6}$ The presence of bridging sulfide ligands enhances the photochemical stability of metal clusters by reinforcing the metal-metal bonds.

Despite the drawbacks mentioned above, metal clusters present several advantages over other inorganic/organic compounds traditionally used in nonlinear optics. Firstly, their constituent heavy atoms introduce more energy sublevels, and consequently more allowed transitions, as compared to organic molecules, and secondly, 
their NLO properties can be easily tuned by changing the constituent elements, oxidation state, structural type and/or outer ligands. Zhang et al. have systematically explored the structure-property correlation within a series of $\mathrm{Mo}(\mathrm{W}) / \mathrm{S}(\mathrm{Se}) / \mathrm{Ag}$ clusters. Five different skeletal cluster cores have been shown to display significant third-order NLO properties. In addition, two different heavy atom effects on the third-order NLO properties of this system have been identified. Substitution of S by Se causes a stronger NLO performance of the system, while there is a sign alternation from the self-defocusing performance upon replacing Mo by $\mathrm{W}^{7}$ Further systematic investigations are needed to establish additional correlations that will ultimately allow us to identify the optimal NLO material.

In the past, our groups have explored the NLO performance of a series of incomplete cuboidal $\left[\mathrm{M}_{3}\left(\mu_{3}-\mathrm{Q}\right)\left(\mu_{2}-\mathrm{Q}\right)_{3} \mathrm{X}_{3}(\text { diphosphine })_{3}\right]^{+}(\mathrm{M}=\mathrm{Mo}, \mathrm{W} ; \mathrm{Q}=\mathrm{S}, \mathrm{Se} ; \mathrm{X}=$ $\mathrm{Cl}, \mathrm{Br})$ cluster complexes and the closely related $\left[\mathrm{M}_{3} \mathrm{Cu}\left(\mu_{3}-\mathrm{Q}\right)\left(\mu_{2}-\mathrm{Q}\right)_{3} \mathrm{X}_{3}(\text { diphosphine })_{3}\right]^{+}$ heterometallic cubane-type compounds. ${ }^{6-18}$ These trinuclear and tetranuclear complexes are all optical limiters $\left(\sigma_{\text {eff }}>\sigma_{0}\right)$ with threshold-limiting fluence decreasing on proceeding from tetranuclear to trinuclear, and from W-containing to Mo containing clusters. Power limiting has also been found in $\operatorname{Mo}_{3}\left(\mu_{3}-S\right)\left(\mu_{2}-S\right)_{3}$ cluster sulfides derivatized with maleonitrile dithiolate, oxalate and thiocyanate ligands, although no clear tendencies could be drawn upon ligand substitution. ${ }^{8}$ In our search for better NLO materials, we have extended our study to other ligands, namely diimines and dithiolenes. Pyridyl complexes were among the first inorganic molecular NLO materials and they still continue to attract significant interest. ${ }^{9,10}$ Furthermore, the nonlinear optical behavior of dithiolene metal complexes is also of interest since $\pi$-extended systems are well-known to enhance the NLO properties of a material. ${ }^{11,12}$ 
Herein, we report the synthesis of seven novel heteroleptic $\operatorname{Mo}_{3}\left(\mu_{3}-S\right)\left(\mu_{2}-S_{2}\right)_{3}$ clusters containing either mixed diimine-halide, $\mathrm{Mo}_{3} \mathrm{~S}_{7} \mathrm{X}_{4}$ (diimine) $(\mathrm{X}=\mathrm{Cl}, \mathrm{Br})$, or diimine-dithiolene ligands, $\mathrm{Mo}_{3} \mathrm{~S}_{7}(\text { dithiolene) })_{2}$ (diimine). The latter represent the first examples of cluster compounds containing mixed diimine/dithiolene ligands. The optical power limiting properties of all these cluster complexes have been evaluated using the Zscan technique. The NLO behavior of the previously reported dinuclear cluster $\left(\mathrm{Et}_{4} \mathrm{~N}\right)_{2}\left[\mathrm{Mo}_{2} \mathrm{O}_{2} \mathrm{~S}_{2}\left(\mathrm{BPyDTS}_{2}\right)_{2}\right]\left(\mathrm{BPyDTS}_{2}=\text { 2-bis-(2-pyridyl)methylene-1,3-dithiolene }\right)^{13}$ has also been investigated, with the aim of finding correlations between nuclearity and third-order optical functions.

\section{Results and discussion}

Synthesis and structure of neutral $\mathrm{Mo}_{3} \mathrm{~S}_{7} \mathrm{X}_{4}$ (diimine) complexes. Homoleptic $\mathrm{Mo}_{3}\left(\mu_{3-}\right.$ $S)\left(\mu_{2}-S_{2}\right)_{3}$ clusters functionalized with a large variety of ligands, such as thiocyanate, dithiocarbamate, catecholate, dithiolene, etc., are readily accessible by ligand substitution reactions starting from the $\left[\mathrm{Mo}_{3} \mathrm{~S}_{7} \mathrm{Br}_{6}\right]^{2-}$ complex. ${ }^{8,14-16}$ In the case of the dithiolene $\mathrm{Mo}_{3} \mathrm{~S}_{7}$ derivatives, upon oxidation these cluster compounds have been used to prepare single molecule magnetic molecular conductors. ${ }^{14}$ Surprisingly, reaction of this precursor with 1,10-phenanthroline or bipyridine derivatives only causes replacement of two bromides on the same metal atom, and affords heteroleptic $\mathrm{Mo}_{3} \mathrm{~S}_{7} \mathrm{Br}_{4}$ (diimine) neutral compounds. The 1,10-phenanthroline derivatives are luminescent materials with potential applications as sensors while the bipyridine clusters adsorbed on titanium oxide nanoparticles are precatalysts in photocatalytic hydrogen evolution processes. ${ }^{17}$ In this work, we have extended this ligand substitution synthetic route, represented in equation 1, to other diimine ligands, namely 4,4'-dimethyl-2,2'-bipyridine (hereinafter, dmbpy), 2,2'-bipyridine (bpy) or 1,10-phenanthroline (phen). 
$\left[\mathrm{Mo}_{3} \mathrm{~S}_{7} \mathrm{X}_{6}\right]^{2-}+$ diimine $\rightarrow \mathrm{Mo}_{3} \mathrm{~S}_{7} \mathrm{X}_{4}($ diimine $)$, with $\mathrm{X}=\mathrm{Cl}$ or $\mathrm{Br}$

Scheme 1 shows the molecular structure of the four isolated $\mathrm{Mo}_{3} \mathrm{~S}_{7} \mathrm{X}_{4}$ (diimine) clusters: $\mathrm{Mo}_{3} \mathrm{~S}_{7} \mathrm{Cl}_{4}$ (dmbpy) (1), $\mathrm{Mo}_{3} \mathrm{~S}_{7} \mathrm{Br}_{4}(\mathrm{dmbpy})$ (2), $\mathrm{Mo}_{3} \mathrm{~S}_{7} \mathrm{Br}_{4}(\mathrm{bpy})(3)$, and $\mathrm{Mo}_{3} \mathrm{~S}_{7} \mathrm{Br}_{4}$ (phen) (4).

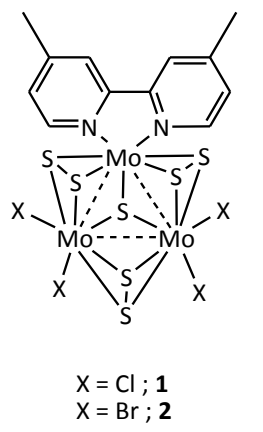

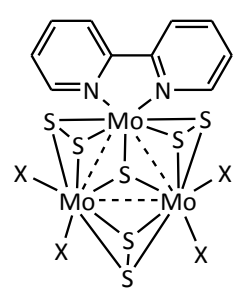

$\mathrm{X}=\mathrm{Br} ; \mathbf{3}$

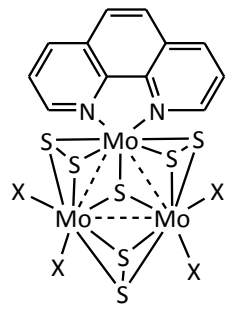

$\mathrm{X}=\mathrm{Br} ; \mathbf{4}$

Scheme 1. Molecular structure of complexes $1-4$.

In order to facilitate the characterization of the highly insoluble neutral $\mathrm{Mo}_{3} \mathrm{~S}_{7} \mathrm{X}_{4}$ (diimine) complexes, we took advantage of the electrophilic character of the axial $\mu-S_{2}{ }^{2-}$ ligands and their tendency to form anionic $\left\{\mathrm{Mo}_{3} \mathrm{~S}_{7} \mathrm{X}_{4} \text { (diimine). } \mathrm{X}\right\}^{-}$ aggregates. ${ }^{18-25}$ Clusters $\mathbf{1}-\mathbf{4}$ could be redissolved in dichloromethane and crystallized in the presence of an excess of $\mathrm{Bu}_{4} \mathrm{NCl}$ (complex $\mathbf{1}$ ) or $\mathrm{Bu}_{4} \mathrm{NBr}$ (complexes $\mathbf{2}-\mathbf{4}$ ) by slow diffusion methods (see Experimental Section). Single crystals of compounds $\left(\mathrm{Bu}_{4} \mathrm{~N}\right)[\mathbf{1} \cdot \mathrm{Cl}],\left(\mathrm{Bu}_{4} \mathrm{~N}\right)[2 \cdot \mathrm{Br}],\left(\mathrm{Bu}_{4} \mathrm{~N}\right)[3 \cdot \mathrm{Br}]$ and $\left(\mathrm{Bu}_{4} \mathrm{~N}\right)[\mathbf{4} \cdot \mathrm{Br}]$ were obtained by slowly diffusing toluene into sample solutions in dichloromethane. The solid-state structures of the cluster complexes were determined by X-ray diffraction.

Figures 1 shows the ORTEP representation of structure $\left(\mathrm{Bu}_{4} \mathrm{~N}\right)[\mathbf{1} \cdot \mathrm{Cl}]$, as representative example of all four structures, with the atom numbering scheme. All these heteroleptic molybdenum clusters crystallize as tetra- $n$-butylammonium salts of anionic aggregates in which neutral cluster molecules of $\left[\mathrm{Mo}_{3}\left(\mu_{3}-\mathrm{S}\right)\left(\mu_{2}-\mathrm{S}_{2}\right)_{3} \mathrm{X}_{4} \mathrm{~L}\right](\mathrm{X}=\mathrm{Cl}$ or $\mathrm{Br}$; 
$\mathrm{L}=$ bpy, phen or dmbpy) participate in non-valence interactions between the sulfur axial atoms (S(3), S(5) and $\mathrm{S}(7)$ in Figure 1) and a chloride/bromide anion. The two nitrogen atoms of the diimine ligand are coordinated to one of the Mo atoms in a chelating mode (average Mo-N distance of 2.216(7) $\AA$ ), and the plane defined by the ligand is oriented almost perpendicularly to the trimetallic plane. The $\mathrm{S}_{\mathrm{ax}} \ldots \mathrm{Cl}$ contacts (average length 2.93(4) $\AA$ ) or $\mathrm{S}_{\mathrm{ax}}$...Br interactions (average length 3.04(9) $\AA$ ) can be explained by the electrophilic character of the sulfur atoms that lie in the axial plane. These kinds of interactions are also observed in related cluster compounds. ${ }^{18-25}$ Intracluster metal-metal and metal-sulfur bond distances are consistent with those for an oxidation state of +4 for the metal, and the presence of single metal-metal bonds (see Table 1). ${ }^{18-25}$ In addition to the crystal structure determinations, the identities of complexes $\left(\mathrm{Bu}_{4} \mathrm{~N}\right)[\mathbf{1}-\mathbf{4}]$ were confirmed by mass spectrometry.

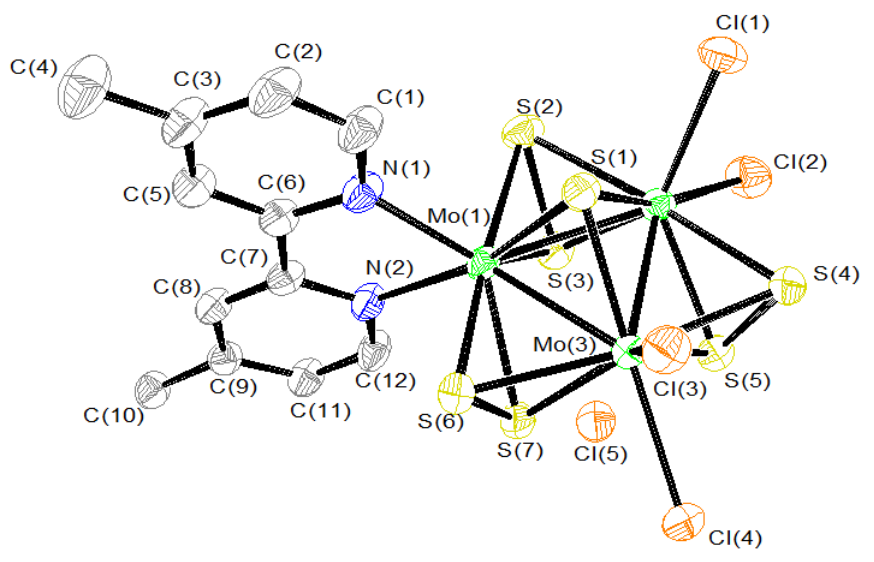

Figure 1. ORTEP representation (50\% probability ellipsoids) of the anionic trinuclear cluster $[\mathbf{1} \cdot \mathrm{Cl}]^{-}$with the atom numbering scheme.

\section{Insert Table 1}

Synthesis of $\mathrm{Moz}_{7}$ (diimine)(dithiolene) 2 complexes. With the aim of extending the chemistry of the $\mathrm{Mo}_{3} \mathrm{~S}_{7} \mathrm{X}_{4}$ (diimine) $(\mathrm{X}=\mathrm{Cl}, \mathrm{Br}$ ) complexes, the previously reported 
clusters $\quad \mathrm{Mo}_{3} \mathrm{~S}_{7} \mathrm{Br}_{4}(\mathrm{dnbpy}) \quad($ dnbpy $=4,4$ '-dinonyl-2,2'-bipyridine) and $\mathrm{Mo}_{3} \mathrm{~S}_{7} \mathrm{Br}_{4}(\mathrm{dcmbpy})\left(\mathrm{dcmbpy}=4,4^{\prime}\right.$-dimethoxycarbonyl-2,2'-bipyridine ${ }^{17}$ were reacted with $\left(\mathrm{Bu}_{4} \mathrm{~N}\right)_{2}\left[\mathrm{Zn}(\mathrm{dmit})_{2}\right](\mathrm{dmit}=1,3$-dithiole-2-thione-4,5-dithiolate $)$, the zinc complex of the dmit ligand. ${ }^{26,27}$ In this way, the neutral complexes $\mathrm{Mo}_{3} \mathrm{~S}_{7}(\mathrm{dnbpy})(\mathrm{dmit})_{2}(\mathbf{5})$ and $\mathrm{Mo}_{3} \mathrm{~S}_{7}(\mathrm{dcmbpy})(\mathrm{dmit})_{2}(\mathbf{6})$ were obtained. Complex $\mathrm{Mo}_{3} \mathrm{~S}_{7}(\mathrm{dcbpy})(\mathrm{dmit})_{2}(\mathbf{7}$, dcbpy $=$ 2,2'-bipyridine-4,4'-dicarboxylic acid) was prepared in situ without prior isolation of the $\mathrm{Mo}_{3} \mathrm{~S}_{7} \mathrm{Br}_{4}$ (dcbpy) complex due to the extremely low solubility of this intermediate in organic solvents, such as dimethylformamide or dimethyl sulfoxide. The approach used for the synthesis of complexes $\mathbf{5} \mathbf{- 7}$ is summarized in Scheme 2 .
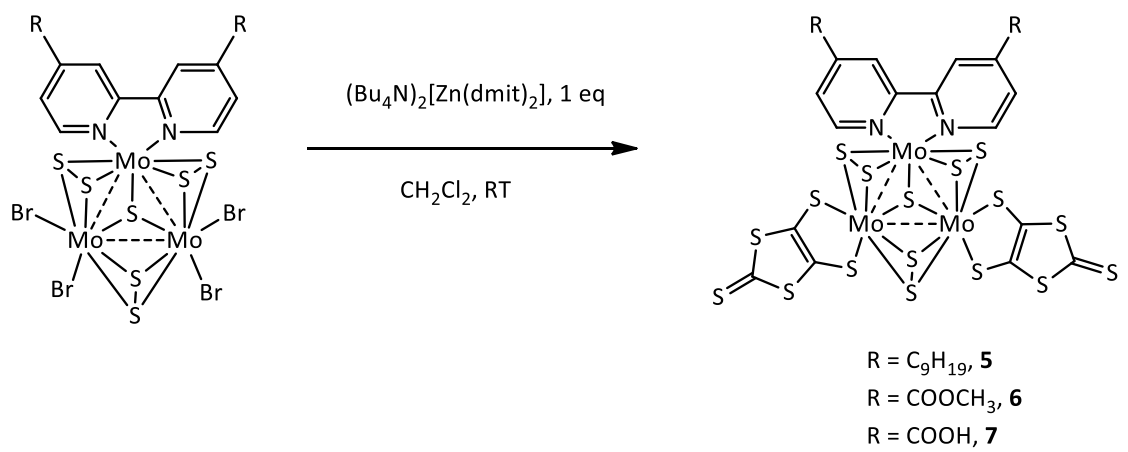

Scheme 2. Synthetic pathway for complexes $5-7$.

Zinc complexes containing dithiolene ligands have been widely used by our group as masked forms of dithiolates which allow the synthesis of tris(dithiolene) trinuclear molybdenum clusters by transmetalation. ${ }^{14-16}$ Apart from helping in the stabilization of the dithiolate ligand, their use is very convenient since $\mathrm{Mo}_{3} \mathrm{~S}_{7}$ cluster units are not stable under the basic conditions that are usually required for the coordination of dithiolene ligands.

Despite being soluble in the reaction mixture, after isolation all resulting neutral products (with the exception of complex 5) were insoluble in common organic solvents. 
It is well-known that in $\left[\mathrm{Mo}_{3}\left(\mu_{3}-\mathrm{S}\right)\left(\mu-\mathrm{S}_{2}\right)_{3}\right]^{4+}$ units the sulfur atoms that lie in the axial plane are slightly electrophilic, and consequently can interact with nucleophilic anions, such as the chloride/bromide ligands replaced by the diimine or dithiolene ligands during the substitution reaction. ${ }^{18-25}$ Consequently, tetra- $n$-butylammonium salts of $\left[\mathrm{Mo}_{3} \mathrm{~S}_{7} \mathrm{X}_{4}(\text { diimine }) \cdot \mathrm{X}\right]^{-}(\mathrm{X}=\mathrm{Cl}, \mathrm{Br})$ or $\left[\mathrm{Mo}_{3} \mathrm{~S}_{7}(\text { diimine })(\text { dithiolene })_{2} \cdot \mathrm{X}\right]^{-}$complexes may be present in solution, which explains the high solubility of the complexes in the reaction mixture. During the purification process such electrostatic interactions were presumably broken, leading to neutral $\mathrm{Mo}_{3} \mathrm{~S}_{7}$ (diimine)(dithiolene) 2 complexes, exhibiting poor solubility in common organic solvents.

The low solubility of complexes $\mathbf{5}-\mathbf{7}$ in common organic solvents limited the number of techniques employed for their characterization. Unfortunately, thus far all attempts to grow single crystals of these compounds suitable for X-ray structural analysis have been unsuccessful. Additionally, the identities of complexes $5-\mathbf{7}$ could not be confirmed from the ESI-MS spectra since it was not possible to ionize them. Alternative techniques (elemental analysis, infrared and UV/Vis spectroscopies) have been used to prove the purity of these products.

In all complexes, there is a good correlation between the calculated and experimental compositions for carbon, hydrogen, nitrogen and sulfur. The characteristic bands of the $\mathrm{Mo}_{3} \mathrm{~S}_{7}$ units, as well as those of their outer diimine and dithiolene ligands were observed in the IR spectra of complexes $5-\mathbf{7}$. These bands were identified on the basis of the stretching frequencies reported for similar cluster complexes. ${ }^{28-31}$ In all cases, a weak band corresponding to the $S_{\text {eq }}-S_{\text {ax }}$ stretching vibration was observed at $c a .516$ $\mathrm{cm}^{-1}$. The vibrations of the Mo $-\mu_{3} \mathrm{~S}$ bonds were observed in the form of multiple bands in the $416-420 \mathrm{~cm}^{-1}$ range. The multiple signals corresponding to the $\mathrm{C}=\mathrm{C}$ stretching 
vibrations of the bipyridine rings appear in the range of $1417-1613 \mathrm{~cm}^{-1}$. The bands assigned to the $\mathrm{C}=\mathrm{S}$ vibrations of the dmit ligand were found in all cases at $1053 \mathrm{~cm}^{-1}$. In addition, further bands were observed due to the vibration of the atoms of the groups appended to the functionalized bipyridine ligands. For instance, in complex $\mathbf{5}$, the $\mathrm{Csp}^{3}$ $\mathrm{H}$ vibration bands of the long alkyl chains in the ligand were found in the range of 2849 $-2920 \mathrm{~cm}^{-1}$. In complex 6 the vibrations of the $\mathrm{C}=\mathrm{O}$ and $\mathrm{C}-\mathrm{O}$ groups were observed as two single bands at $1732 \mathrm{~cm}^{-1}$ and $1267 \mathrm{~cm}^{-1}$, respectively. Finally, in complex 7, containing the analogous dcbpy ligand, apart from the $\mathrm{C}=\mathrm{O}$ and $\mathrm{C}-\mathrm{S}$ bands discussed for complex $\mathbf{6}$, the vibrations of the terminal $\mathrm{O}-\mathrm{H}$ groups were found as a broad band centered at $3446 \mathrm{~cm}^{-1}$.

Optical Limiting Properties. The linear optical and optical power limiting properties of clusters 1 - 7 were examined. Linear optical spectra are displayed in Figures 2 and 3, respectively. Important spectral data are listed in Table 2 . When we were able to examine the clusters across a range of solvents of different polarities (dichloromethane, tetrahydrofuran, dimethylformamide), they exhibited significant solvatochromism. This was not explored further due to variable solubility in the less polar solvents, and consequently the studies summarized below were undertaken in dimethylformamide. 


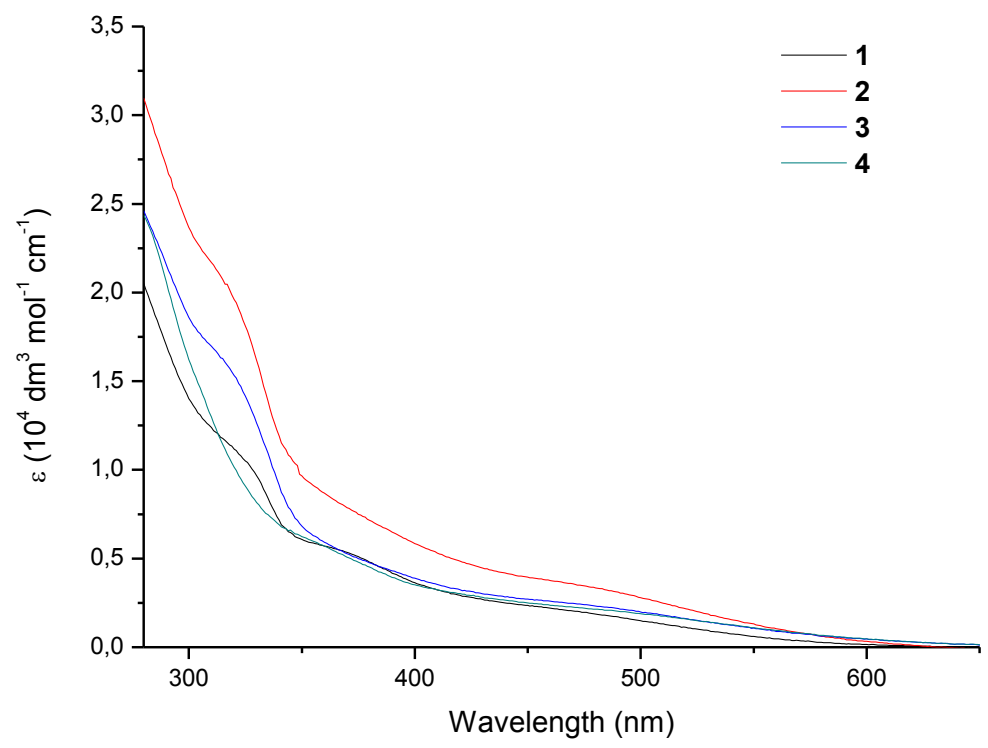

Figure 2. Linear optical spectra for complexes $\mathbf{1}-\mathbf{4}$ in dimethylformamide solution.

The UV-visible spectra of complexes $\mathbf{1}$ - 7 reveal intense bands at highest energy $\left(\lambda_{1}, 304-342 \mathrm{~nm}\right)$, less intense bands at lower energy $\left(\lambda_{2}, 335-427 \mathrm{~nm}\right)$, and weak bands at lowest energy $\left(\lambda_{3}, 446-538 \mathrm{~nm}\right)$. The cluster $\left(\mathrm{Et}_{4} \mathrm{~N}\right)_{2}\left[\mathrm{Mo}_{2} \mathrm{O}_{2} \mathrm{~S}_{2}\left(\mathrm{BPyDTS}_{2}\right)_{2}\right]$ is structurally distinct, ${ }^{13}$ possessing an $\mathrm{Mo}_{2}\left(\mu_{2}-\mathrm{S}\right)_{2}(\mathrm{O})_{2}$ core, in contrast to the other heteroleptic complexes which possess $\mathrm{Mo}_{3}\left(\mu_{3}-\mathrm{S}\right)\left(\mu_{2}-\mathrm{S}_{2}\right)_{3}$ cores; its absorption maxima are at lowest energy across the series of complexes presented in this work. For the latter, the lowest energy $\left(\lambda_{3}\right)$ bands follow the wavelength order: complex $7>$ complex $5>$ complex $\mathbf{6}=$ complex $\mathbf{4}>$ complex $\mathbf{3}>$ complex $\mathbf{2}>$ complex $\mathbf{1}$, with the dmit (1,3-dithia2-thione-4,5-dithiolate) ligated clusters 5 - 7 exhibiting the lowest energy maxima, and the chloro-ligated cluster $\mathbf{1}$ exhibiting the highest energy maximum. 


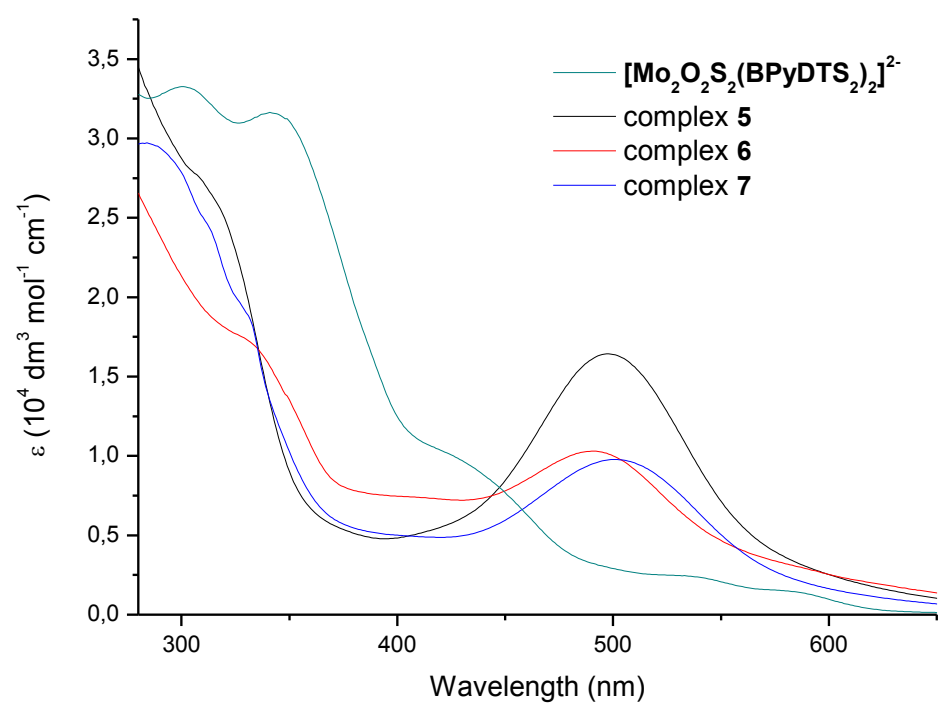

Figure 3. Linear optical spectra for complexes $\left(\mathrm{Et}_{4} \mathrm{~N}\right)_{2}\left[\mathrm{Mo}_{2} \mathrm{O}_{2} \mathrm{~S}_{2}\left(\mathrm{BPyDTS}_{2}\right)_{2}\right]^{13}$ and $\mathbf{5}-$ 7 in dimethylformamide.

The UV-visible spectra of the eight clusters contain broad low-intensity absorptions through areas of the visible region of the spectrum, suggestive of potential as broad-band optical limiters. Relevant data for optical limiting merit from Z-scan measurements (see Experimental) are collected in Table 2. All clusters absorb weakly at the specific wavelengths chosen to assess their optical limiting performance.

\section{Insert Table 2}

As we have discussed previously, closed-aperture Z-scan is usually used to derive the nonlinear refractive index $n_{2}$ by examining self-focusing or self-defocusing phenomena, while open-aperture Z-scan can afford the nonlinear absorption properties by monitoring the total transmission through a sample. ${ }^{32}$ Both were employed in the present studies. The closed-aperture scans show characteristic self-defocusing traces. The 
negative refractive nonlinearity may possess contributions from a variety of different mechanisms, including thermal effects. Therefore, no further comment is made here.

Transmission vs. fluence plots were generated, where the fluence is the energy of the laser pulse per unit area. Examples of each class of complex are shown in Figure 4. For comparative purposes, a threshold limiting fluence $F_{15 \%}$ (defined as the incident fluence needed to reduce the transmittance through a sample by $15 \%$ ) has been used to assess the relative optical limiting merit of these clusters. The results are tabulated in Table 2. 


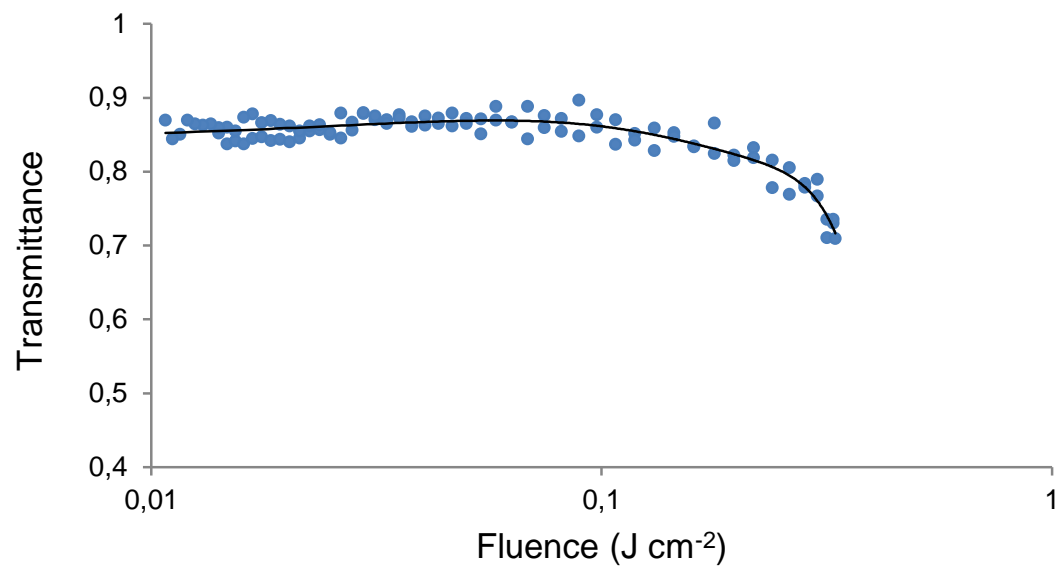

(a)

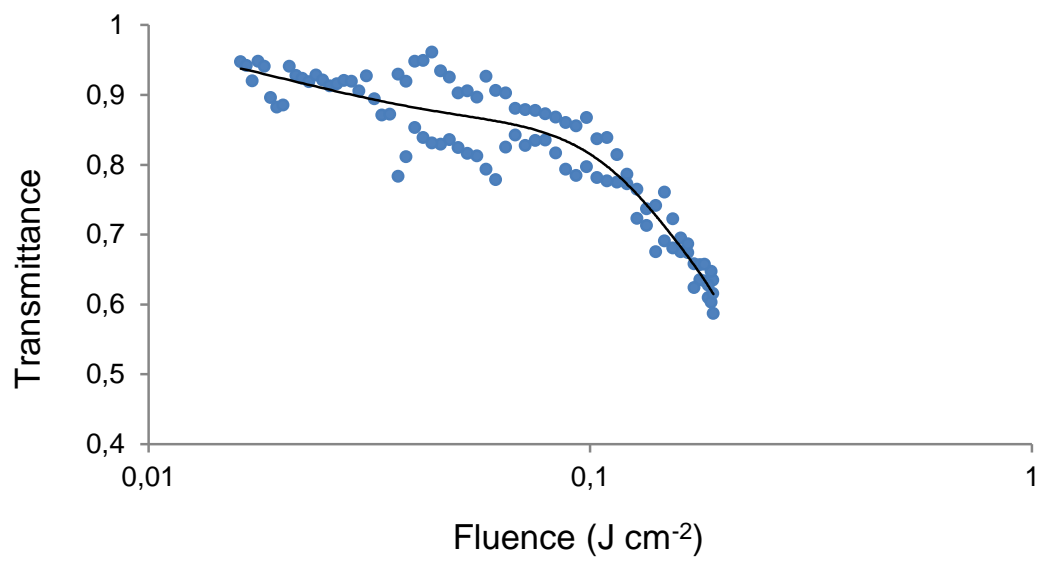

(b)

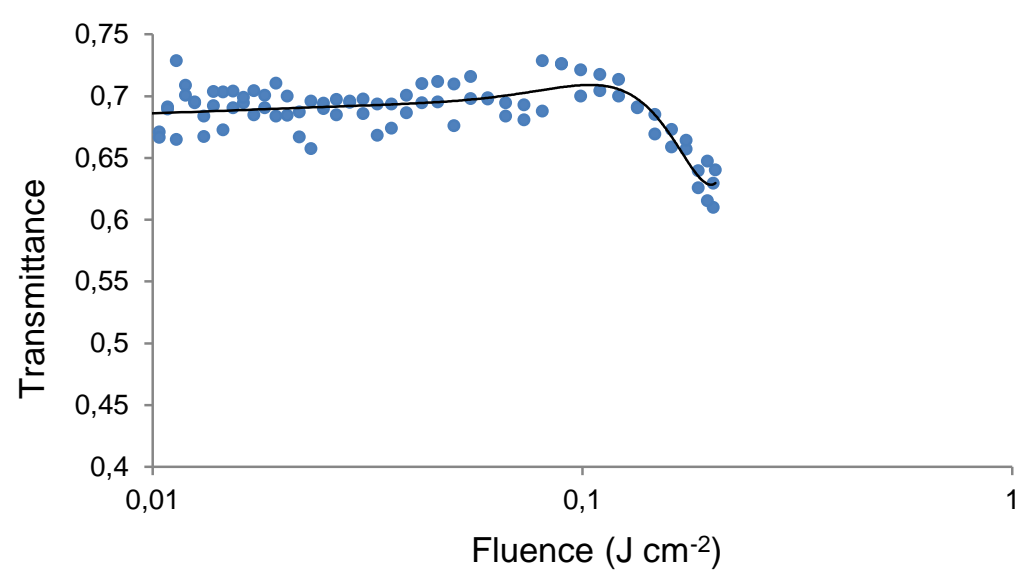

(c)

Figure 4. Optical limiting behavior of (a) $\left(\mathrm{Et}_{4} \mathrm{~N}\right)_{2}\left[\mathrm{Mo}_{2} \mathrm{O}_{2} \mathrm{~S}_{2}\left(\mathrm{BPyDTS}_{2}\right)_{2}\right]^{13}$, (b) complex 3, and (c) complex 5. 
The threshold limiting fluences at $570 \mathrm{~nm}$ follow the trend: complex $\mathbf{3} \approx$ complex $\mathbf{2}<$ complex $5 \approx$ complex $7=$ complex $4<$ complex $\mathbf{6}<\operatorname{complex} \mathbf{1}<$ $\left[\mathrm{Mo}_{2} \mathrm{O}_{2} \mathrm{~S}_{2}\left(\mathrm{BPyDTS}_{2}\right)_{2}\right]^{2-}$. The optical limiting merit therefore increases on increasing the metal content (proceeding from dinuclear $\left[\mathrm{Mo}_{2} \mathrm{O}_{2} \mathrm{~S}_{2}\left(\mathrm{BPyDTS}_{2}\right)_{2}\right]^{2-}$ to the trinuclear clusters). Assuming a three-state reverse saturable absorption model and employing literature expressions, effective cross-sections of the dominant excited states can be calculated. ${ }^{33}$ The energy transmittance of the cell with a Gaussian beam is given by:

$$
T=(1 \quad R)^{2} \frac{\exp \left(\quad{ }_{0} L\right)}{q} \ln (1+q)
$$

where

$$
q=\left(\begin{array}{lll}
1 & R
\end{array}\right)\left[1 \quad \exp \left({ }_{0} L\right)\right]_{\text {eff }} F_{0} / 2 F_{s}
$$

and $R$ is the reflection coefficient, $\alpha_{0}$ is the low power absorption coefficient, $F_{0}$ is the fluence and $F_{s}$ is the saturation fluence defined as:

$$
F_{s}=\frac{\hbar}{0}
$$

and

$$
\text { eff }=\frac{\text { eff } \quad 0}{0}
$$

where $\sigma_{\text {eff }}$ is the effective excited-state cross-section and $\sigma_{0}$ is the ground-state crosssection. Note that these expressions are derived assuming that the lifetime of the state active in the reverse saturable absorption process is longer than the laser pulse duration. Note also that the effective excited-state cross section should only be treated as a measure of the power limiting ability of the substance under specific experimental conditions; it 
may contain contributions from several different excited states with different properties (e.g. from states of different spin). The values of the excited-state cross-sections $\sigma_{e f f}$ for the clusters are given in Table 1. With the exception of the dinuclear cluster $\left[\mathrm{Mo}_{2} \mathrm{O}_{2} \mathrm{~S}_{2}\left(\mathrm{BPyDTS}_{2}\right)_{2}\right]^{2-}$, the $\sigma_{\text {eff }}$ values are larger than those of the corresponding ground-state cross-sections $\sigma_{0}$. In other words, all trinuclear clusters in the present study are optical limiters.

Cluster 6 was also examined at 500, 532, and $640 \mathrm{~nm}$, in addition to the aforementioned measurement at $570 \mathrm{~nm}$. For $\mathbf{6}, \sigma_{\text {eff }}$ and $\sigma_{\text {eff }} / \sigma_{0}$ data vary with the wavelength of study. At the shorter wavelengths, the ground-state cross-sections are larger than the excited-state cross-sections, and the cluster no longer functions as an optical limiter. These data are consistent with $\mathbf{6}$ (and by implication the other clusters in the present study) functioning as an optical limiter via an RSA mechanism at longer wavelengths (including the benchmark wavelength of $570 \mathrm{~nm}$ ).

The values of $\sigma_{\text {eff }}$ derived in the present experiments can in principle be compared to those presented by us before, ${ }^{8,32,34}$ but comparisons between values obtained in these different data collection runs should be cautious, since the effective cross section values are likely to depend to a certain degree on the details of a power limiting experiment such as the pulse duration, the geometric parameters of the laser beam, etc. Comparison between data collected in different laboratories should be even more circumspect. We have sought to benchmark the present data against well-studied materials. Under our conditions, Rhodamine B in acidified DMF proved to be photosensitive (bleaching was observed). $\mathrm{C}_{60}$ as a suspension in $\operatorname{DMF}\left(\sigma_{0} 1.8 \times 10^{-18} \mathrm{~cm}^{-2}, \sigma_{\text {eff }} 33.0 \times 10^{-18} \mathrm{~cm}^{2}, \sigma_{\text {eff }} / \sigma_{0}\right.$ 18.1) proved more efficient than the clusters, but further comment is not warranted as the 
suspension of $\mathrm{C}_{60}$ in our study is likely to be functioning as an optical limiter largely by scattering, rather than attenuation by excited-state absorption.

The present $\sigma_{e f f}$ data (complex $5>$ complex $\mathbf{6}>$ complex $7>$ complex $\mathbf{4} \approx$ complex $\mathbf{2} \approx$ complex $\mathbf{3}>$ complex $\mathbf{1}$ ) are suggestive that extending the $\pi$-delocalization (by introducing dmit ligands) and lowering the energy of the $\pi$-system of the bipyridine ligands in the series (by appending electron-withdrawing carboxylic acid or methyl ester groups), leads to an improvement in $\sigma_{\text {eff. }}$. While minimizing speculative interpretation, this is consistent with the relevant excited states having significant ligand character, and with tuning of the energy levels being a key determinant of optical limiting merit. Further comment on the optical power-limiting mechanism requires time-resolved experiments.

\section{Experimental Section}

General Procedures. Elemental analysis was performed on an EA $3000 \mathrm{CHN}$ analyser. ${ }^{1} \mathrm{H}-\mathrm{NMR}$ spectra were recorded on a Varian Mercury Vx $300 \mathrm{MHz}$ instrument, using deuterated solvents, and were referenced to internal tetramethylsilane. IR spectra were recorded in the $400-4000 \mathrm{~cm}^{-1}$ range on a Jasco $6200 \mathrm{FT} / \mathrm{IR}$ spectrometer using $\mathrm{KBr}$ pellets. Characteristic IR bands were assigned on the basis of those of previously reported complexes. Electronic spectra in the different solvents were recorded on a HewlettPackard UV/Vis 8453 spectrophotometer. Electrospray ionization mass spectra were recorded on a triple quadrupole mass spectrometer (Micromass Quattro LC). The chemical composition of each peak in the scan mode was assigned by comparing the isotope experimental pattern with that calculated using the MassLynx 4.1 program. 
Unless otherwise stated, all synthetic reactions were carried out under nitrogen-gas atmosphere using standard Schlenk techniques. High-purity solvents for synthesis were used. Dichloromethane was further purified by using an MBRAUN SPS-800 system. $\mathrm{N}, \mathrm{N}$-dimethylformamide (DMF) was degassed in vacuo.

Optical Limiting Studies. Optical measurements were performed on dimethylformamide solutions of samples placed in $1 \mathrm{~mm}$ glass cells. Linear optical spectra were obtained on a Varian Cary 5 spectrophotometer over the spectral range 270$800 \mathrm{~nm}$ at the Research School of Chemistry (RSC), Australian National University (ANU). The light source used for the determination of power limiting properties was an Opolette (HE) 355 II (Opotek), located at RSC, ANU. This is a single-housing tuneable ns laser system in which the third harmonic from a Nd:YAG laser (355 nm pump wavelength, $20 \mathrm{~Hz}$ repetition rate, $5 \mathrm{~ns}$ pulse length) pumps an OPO (tuning range 410$2200 \mathrm{~nm}$, peak OPO energy $10 \mathrm{~mJ}$, spectral linewidth $4-7 \mathrm{~cm}^{-1}$ ). The optical power limiting experiments were performed on solutions of concentrations $0.07-0.35 \% \mathrm{w} / \mathrm{w}$. The properties were assessed by the open-aperture Z-scan technique at $570 \mathrm{~nm}$ at which the samples had low, but non-zero, linear absorption (corresponding to $\varepsilon$ values of 307 $4411 \mathrm{M}^{-1} \mathrm{~cm}^{-1}$ at the measurement wavelength). Additional studies of cluster $\mathbf{6}$ were undertaken at 500,532, and $640 \mathrm{~nm}$. The data from the power limiting curves obtained by the open-aperture Z-scan technique were then converted into transmittance-fluence plots assuming a Gaussian character of the beam, the $\mathrm{w}_{0}$ parameter of the beam being determined from closed-aperture Z-scan results. The clusters were tested and found to be photochemically stable at light intensities up to $65 \mathrm{MW} \mathrm{cm}^{-2}$, as judged by the symmetrical nature of the Z-scan curve. 
Starting Materials. Commercially available starting materials (4,4'-dimethyl-2,2'bipyridine, 2,2'-bipyridine and 1,10-phenanthroline) were obtained either from SigmaAldrich or Acros, and used as received without further purification. The preparation of the ligand 2,2'-bipyridine-4,4'-dicarboxylic acid is described elsewhere. ${ }^{35}$ The complex $(\mathrm{TBA})_{2}\left[\mathrm{Zn}(\mathrm{dmit})_{2}\right]$ was synthesized by following the approach described by Steimecke. ${ }^{26,27}$ The thioclusters $\left(\mathrm{Bu}_{4} \mathrm{~N}\right)_{2}\left[\mathrm{Mo}_{3} \mathrm{~S}_{7} \mathrm{Br}_{6}\right]$ and $\left(\mathrm{Bu}_{4} \mathrm{~N}\right)_{2}\left[\mathrm{Mo}_{3} \mathrm{~S}_{7} \mathrm{Cl}_{6}\right]$ were prepared from $\left(\mathrm{NH}_{4}\right)_{2}\left[\mathrm{Mo}_{3} \mathrm{~S}_{13}\right] \cdot \mathrm{nH}_{2} \mathrm{O}^{36}$ as described previously ${ }^{37}$, but using $\mathrm{Bu} 4 \mathrm{NBr}$ and $\mathrm{Bu}_{4} \mathrm{NCl}$, respectively, to precipitate the final compound. The complexes $\mathrm{Mo}_{3} \mathrm{~S}_{7} \mathrm{Br}_{4}(\mathrm{dnbpy}),\left(\mathrm{Bu}_{4} \mathrm{~N}\right)\left[\mathrm{Mo}_{3} \mathrm{~S}_{7} \mathrm{Br}_{5}(\mathrm{dcmbpy})\right]^{17}$ and $\left(\mathrm{Et}_{4} \mathrm{~N}\right)_{2}\left[\mathrm{Mo}_{2} \mathrm{O}_{2} \mathrm{~S}_{2}\left(\mathrm{BPyDTS}_{2}\right)_{2}\right]^{13}$ were prepared by our group in the past.

$\mathrm{Mos}_{3} \mathrm{~S}_{7} \mathrm{Cl}_{4}(\mathbf{d m b p y})$ (1). The cluster $\left(\mathrm{Bu}_{4} \mathrm{~N}\right)_{2}\left[\mathrm{Mo}_{3} \mathrm{~S}_{7} \mathrm{Cl}_{6}\right](100 \mathrm{mg}, 0.083 \mathrm{mmol})$ and 4 equivalents of commercial 4,4'-dimethyl-2,2'-bipyridine (62 mg, $0.33 \mathrm{mmol}$ ) were mixed with $\mathrm{CH}_{2} \mathrm{Cl}_{2}(20 \mathrm{~mL})$ and heated to reflux for 1 day. The reddish-orange solution was taken to dryness by rotary evaporation. The orange residue was washed with methanol, a few $\mathrm{mL}$ of acetonitrile and dichloromethane, and finally diethyl ether. An orange powder was obtained. Yield: $67 \mathrm{mg}(96 \%)$. ESI-MS $\left(\mathrm{CH}_{2} \mathrm{Cl}_{2} / \mathrm{CH}_{3} \mathrm{CN}, 20 \mathrm{~V},-\right): \mathrm{m} / \mathrm{z}=874.3$ $[\mathrm{MCl}]^{-}$. Elemental analysis (\%) calcd. for $\mathrm{C}_{12} \mathrm{H}_{12} \mathrm{Cl}_{4} \mathrm{Mo}_{3} \mathrm{~N}_{2} \mathrm{~S}_{7}: \mathrm{C}, 17.19 ; \mathrm{H}, 1.44 ; \mathrm{N}, 3.34$; found $\mathrm{C}, 17.5 ; \mathrm{H}, 1.76 ; \mathrm{N}, 3.45$. UV/Vis (DMSO): $\lambda_{\max }(\varepsilon)=381(1654), 447(1056) \mathrm{nm}$ $\left(\mathrm{M}^{-1} \mathrm{~cm}^{-1}\right)$.

$\mathrm{Mo3S}_{7} \mathrm{Br}_{4}(\mathbf{d m b p y})$ (2). The starting material $\left(\mathrm{Bu}_{4} \mathrm{~N}\right)_{2}\left[\mathrm{Mo}_{3} \mathrm{~S}_{7} \mathrm{Br}_{6}\right](100 \mathrm{mg}, 0.068 \mathrm{mmol})$ and an excess of 4,4'-dimethyl-2,2'-bipyridine (50 $\mathrm{mg}, 0.27 \mathrm{mmol}$ ) were mixed with $\mathrm{CH}_{2} \mathrm{Cl}_{2}(30 \mathrm{~mL})$ and stirred overnight at room temperature. The reddish-orange solution was filtered and taken to dryness by rotary evaporation. The solid residue was washed with methanol, acetonitrile and diethyl ether to afford an orange powder. Yield: $57 \mathrm{mg}$ 
(82\%). ${ }^{1} \mathrm{H}-\mathrm{NMR}\left(\mathrm{d}_{6}-\mathrm{DMSO}, 300 \mathrm{MHz}\right): 2.59(\mathrm{~s}, 6 \mathrm{H}), 7.73(\mathrm{~m}, 2 \mathrm{H}), 8.78(\mathrm{~m}, 2 \mathrm{H}), 9.19$ (d, 1H), 9.57 ppm (m, 1H). ESI-MS $\left(\mathrm{CH}_{2} \mathrm{Cl}_{2} / \mathrm{CH}_{3} \mathrm{CN}, 20 \mathrm{~V},-\right): \mathrm{m} / \mathrm{z}=1096.0[\mathrm{MBr}]^{-}$, 1052.3 [MCl] $]^{-}, 1006.3[\mathrm{M}-\mathrm{Br}+2 \mathrm{Cl}]$. Elemental analysis (\%) calcd. for $\mathrm{C}_{12} \mathrm{H}_{12} \mathrm{Br}_{4} \mathrm{Mo}_{3} \mathrm{~N}_{2} \mathrm{~S}_{7}$ : C, 14.18; H, 1.19; N, 2.76; found C, 14.3; H, 1.4; N, 2.4. UV/Vis (DMSO): $\lambda_{\max }(\varepsilon)=450(2389) \mathrm{nm}\left(\mathrm{M}^{-1} \mathrm{~cm}^{-1}\right)$.

$\mathrm{Mo3}_{7} \mathrm{Br}_{4}$ (bpy) (3). The complex $\left(\mathrm{Bu}_{4} \mathrm{~N}\right)_{2}\left[\mathrm{Mo}_{3} \mathrm{~S}_{7} \mathrm{Br}_{6}\right](100 \mathrm{mg}, 0.068 \mathrm{mmol})$ and an excess of 2,2'-bipyridine (53 mg, $0.34 \mathrm{mmol}$ ) were stirred overnight at room temperature. The red mixture was filtered, and the filtrate was taken to dryness by rotary evaporation. The sticky solid residue was washed with methanol, acetonitrile, dichloromethane and diethyl ether. An orange solid was obtained. Yield: $45 \mathrm{mg}(67 \%) .{ }^{1} \mathrm{H}-\mathrm{NMR}$ (d6-DMSO, $300 \mathrm{MHz}): 7.91(\mathrm{~m}, 2 \mathrm{H}), 8.48(\mathrm{q}, 2 \mathrm{H}), 8.91(\mathrm{~m}, 2 \mathrm{H}), 9.36(\mathrm{~d}, 1 \mathrm{H}), 9.81 \mathrm{ppm}(\mathrm{d}, 1 \mathrm{H})$. ESI-MS $\left(\mathrm{CH}_{2} \mathrm{Cl}_{2} / \mathrm{CH}_{3} \mathrm{CN}, 20 \mathrm{~V},-\right): \mathrm{m} / \mathrm{z}=1068.0[\mathrm{MBr}]^{-}, 1024.0[\mathrm{MCl}]^{-}, 979.1[\mathrm{M}-\mathrm{Br}$ $+2 \mathrm{Cl}]^{-}$. Elemental analysis $(\%)$ calcd. for $\mathrm{C}_{10} \mathrm{H}_{8} \mathrm{Br}_{4} \mathrm{Mo}_{3} \mathrm{~N}_{2} \mathrm{~S}_{7}: \mathrm{C}, 12.16 ; \mathrm{H}, 0.82 ; \mathrm{N}, 2.84$; found $\mathrm{C}, 12.40 ; \mathrm{H}, 1.10 ; \mathrm{N}, 2.85$. UV/Vis (DMSO): $\lambda_{\max }(\varepsilon)=458(2258) \mathrm{nm}\left(\mathrm{M}^{-1} \mathrm{~cm}^{-1}\right)$.

$\mathrm{Mo3S}_{7} \mathrm{Br}_{4}$ (phen) (4). The cluster species $\left(\mathrm{Bu}_{4} \mathrm{~N}\right)_{2}\left[\mathrm{Mo}_{3} \mathrm{~S}_{7} \mathrm{Br}_{6}\right](100 \mathrm{mg}, 0.068 \mathrm{mmol})$ and 5 equivalents of commercially available 1,10-phenanthroline (62 mg, $0.34 \mathrm{mmol}$ ) were allowed to stir overnight at room temperature. After removing the orange precipitate by filtration, the red filtrate was taken to dryness. The reddish-orange solid was thoroughly washed with methanol, acetonitrile, dichloromethane and diethyl ether. Yield: $55 \mathrm{mg}$ (69 \%). ${ }^{1} \mathrm{H}-\mathrm{NMR}$ (d6-DMSO, $\left.300 \mathrm{MHz}\right): 8.27$ (m, 2H), 8.41 (s, 2H), 9.13 (m, 2H), 9.65-9.80 (m, 1H), 10.12 ppm (m, 1H). ESI-MS $\left(\mathrm{CH}_{2} \mathrm{Cl}_{2} / \mathrm{CH}_{3} \mathrm{CN}, 20 \mathrm{~V},-\right): \mathrm{m} / \mathrm{z}=1092.0[\mathrm{MBr}]^{-}$, 1048.0 [MCl] $]^{-}$Elemental analysis (\%) calcd. for $\mathrm{C}_{12} \mathrm{H}_{8} \mathrm{Br}_{4} \mathrm{Mo}_{3} \mathrm{~N}_{2} \mathrm{~S}_{7}$ : C, 14.24; $\mathrm{H}, 0.80$; $\mathrm{N}, 2.77$; found $\mathrm{C}, 14.55 ; \mathrm{H}, 1.30 ; \mathrm{N}, 2.65$. UV/Vis $(\mathrm{DMSO}): \lambda_{\max }(\varepsilon)=453(3149) \mathrm{nm}$ $\left(\mathrm{M}^{-1} \mathrm{~cm}^{-1}\right)$. 
$\mathrm{Mo3}_{7}(\mathbf{d n b p y})(\mathbf{d m i t})_{2}$ (5). To a solution of $\mathrm{Mo}_{3} \mathrm{~S}_{7} \mathrm{Br}_{4}(\mathrm{dnbpy})(300 \mathrm{mg}, 0.24 \mathrm{mmol})$ in $\mathrm{CH}_{2} \mathrm{Cl}_{2}(75 \mathrm{~mL}), 1.1$ equivalents of $\left(\mathrm{Bu}{ }_{4} \mathrm{~N}\right)_{2}\left[\mathrm{Zn}(\mathrm{dmit})_{2}\right](252 \mathrm{mg}, 0.27 \mathrm{mmol})$ were added. The solution was stirred for $6 \mathrm{~h}$ at room temperature. The dark red mixture was filtered, and the filtrate was taken to dryness by rotary evaporation. The sticky dark residue was thoroughly washed with methanol, water, acetonitrile, and diethyl ether. A dark powder was obtained. The reaction is almost quantitative. Yield: $315 \mathrm{mg}$ (99 \%). Elemental analysis (\%) calcd. for $\mathrm{C}_{34} \mathrm{H}_{44} \mathrm{Mo}_{3} \mathrm{~N}_{2} \mathrm{~S}_{17}$ : C, 31.09; H, 3.38; N, 2.13; S, 41.50; found $\mathrm{C}$, 31.3; H, 3.7; N, 2.1; S, 41.2. IR (KBr, cm $\left.{ }^{-1}\right): 2920$ (s, Csp $\left.{ }^{3}-\mathrm{H}\right) ; 2849$ (s, Csp $\left.{ }^{3}-\mathrm{H}\right) ; 1613$ (m, C=C); $1542(\mathrm{w}, \mathrm{C}=\mathrm{C}) ; 1457(\mathrm{~m}, \mathrm{C}=\mathrm{C}) ; 1417(\mathrm{~m}, \mathrm{C}=\mathrm{C}) ; 1053$ (s, C=S); 1023 (s, C$\mathrm{S}) ; 516\left(\mathrm{w}, \mathrm{S}_{\mathrm{eq}}-\mathrm{S}_{\mathrm{ax}}\right) ; 420\left(\mathrm{w}, \mathrm{Mo}-\mu \mathrm{S}_{3}\right)$. UV/Vis (DMSO): $\lambda_{\max }(\varepsilon)=326$ sh (17 550), 492 (11 665) nm $\left(\mathrm{M}^{-1} \mathrm{~cm}^{-1}\right)$.

$\mathrm{Mos}_{7}(\mathbf{d c m b p y})(\mathbf{d m i t})_{2}(\mathbf{6})$. To a solution of $\left(\mathrm{Bu}_{4} \mathrm{~N}\right)\left[\mathrm{Mo}_{3} \mathrm{~S}_{7} \mathrm{Br}_{5}(\mathrm{dcmbpy})\right](360 \mathrm{mg}, 0.25$ $\mathrm{mmol})$ in $\mathrm{CH}_{2} \mathrm{Cl}_{2}(60 \mathrm{~mL})$, solid $\left(\mathrm{Bu}_{4} \mathrm{~N}\right)_{2}\left[\mathrm{Zn}(\mathrm{dmit})_{2}\right](240 \mathrm{mg}, 0.25 \mathrm{mmol})$ was added in one portion. The dark purple mixture was stirred for $6.5 \mathrm{~h}$ at room temperature. After filtration, the solution was taken to dryness by rotary evaporation. The sticky dark residue was thoroughly washed with methanol, water, hot acetonitrile (until colorless filtrate), and diethyl ether. A dark powder, insoluble in common organic solvents, was obtained. Yield: $240 \mathrm{mg}(82 \%)$. Elemental analysis (\%) calcd. for $\mathrm{C}_{20} \mathrm{H}_{12} \mathrm{Mo}_{3} \mathrm{~N}_{2} \mathrm{O}_{4} \mathrm{~S}_{17}: \mathrm{C}, 20.40$; $\mathrm{H}, 1.03 ; \mathrm{N}, 2.38$; found $\mathrm{C}, 20.4 ; \mathrm{H}, 1.3 ; \mathrm{N}, 2.4 . \mathrm{IR}\left(\mathrm{KBr}, \mathrm{cm}^{-1}\right): 1732(\mathrm{~s}, \mathrm{C}=\mathrm{O}) ; 1617$ (m, $\mathrm{C}=\mathrm{C}) ; 1542$ (w, C=C); 1437 (m, C=C); 1267 (m, C-O); 1053 (s, C=S); 1029 (s, C-O); $517\left(\mathrm{w}, \mathrm{S}_{\mathrm{eq}}-\mathrm{S}_{\mathrm{ax}}\right) ; 420\left(\mathrm{w}, \mathrm{Mo}-\mu \mathrm{S}_{3}\right) . \mathrm{UV} / \mathrm{Vis}(\mathrm{DMSO}): \lambda_{\max }(\varepsilon)=326 \mathrm{sh}(6730), 490(4513)$ $\mathrm{nm}\left(\mathrm{M}^{-1} \mathrm{~cm}^{-1}\right)$.

$\operatorname{Mos}_{7}(\mathbf{d c b p y})(\mathbf{d m i t})_{2}$ (7). The synthesis of complex 7 was carried out in two steps. The cluster complex $\left(\mathrm{Bu}_{4} \mathrm{~N}\right)_{2}\left[\mathrm{Mo}_{3} \mathrm{~S}_{7} \mathrm{Br}_{6}\right](500 \mathrm{mg}, 0.34 \mathrm{mmol})$ and 5.5 equivalents of 2,2'- 
bipyridine-4,4'-dicarboxylic acid (460 mg, $1.88 \mathrm{mmol}$ ) were mixed with degassed DMF $(100 \mathrm{~mL})$. The mixture was heated to $125-130{ }^{\circ} \mathrm{C}$ for $20 \mathrm{~h}$. The red solution, presumably containing the species $\left(\mathrm{Bu}_{4} \mathrm{~N}\right)\left[\mathrm{Mo}_{3} \mathrm{~S}_{7} \mathrm{Br}_{5}(\mathrm{dcbpy})\right]$, was allowed to cool to room temperature. The excess of the ligand precipitated as a white crystalline solid, which was not removed. To this suspension, 1.1 equivalents of solid $\left(\mathrm{Bu}_{4} \mathrm{~N}\right)_{2}\left[\mathrm{Zn}(\mathrm{dmit})_{2}\right](353 \mathrm{mg}$, $0.37 \mathrm{mmol}$ ) were added. The deep purple mixture was stirred overnight at room temperature. The white solid was removed by filtration, and the filtrate was concentrated by rotary evaporation. The solution was cooled to $-30{ }^{\circ} \mathrm{C}$ to allow the complete precipitation of the excess of the ligand. After filtration, the solution was taken to dryness by rotary evaporation. Then the dark residue was thoroughly washed with methanol, water, hot acetonitrile and diethyl ether to afford a dark powder, insoluble in common organic solvents. Yield: $290 \mathrm{mg}(74 \%)$. Elemental analysis (\%) calcd. for $\mathrm{C}_{18} \mathrm{H}_{8} \mathrm{Mo}_{3} \mathrm{~N}_{2} \mathrm{O}_{4} \mathrm{~S}_{17}: \mathrm{C}, 18.81 ; \mathrm{H}, 0.70 ; \mathrm{N}, 2.44$; found $\mathrm{C}, 18.5 ; \mathrm{H}, 1.0 ; \mathrm{N}, 2.5$. IR (KBr, $\left.\mathrm{cm}^{-1}\right): 3446$ (br, OH); $1716(\mathrm{~m}, \mathrm{C}=\mathrm{O}) ; 1542(\mathrm{~m}, \mathrm{C}=\mathrm{C}) ; 1458(\mathrm{~m}, \mathrm{C}=\mathrm{C}) ; 1053$ (s, C=S); $516\left(\mathrm{w}, \mathrm{S}_{\mathrm{eq}}-\mathrm{S}_{\mathrm{ax}}\right) ; 416\left(\mathrm{~m}, \mathrm{Mo}-\mu \mathrm{S}_{3}\right) . \mathrm{UV} / \mathrm{Vis}(\mathrm{DMSO}): \lambda_{\max }(\varepsilon)=336 \mathrm{sh}(12181), 484$ (5475) $\mathrm{nm}\left(\mathrm{M}^{-1} \mathrm{~cm}^{-1}\right)$.

Structural Determination. Diffraction data for compounds $\left(\mathrm{Bu}_{4} \mathrm{~N}\right)[\mathbf{1} \cdot \mathrm{Cl}] \cdot 3 \mathrm{CH}_{2} \mathrm{Cl}_{2}$, $\left(\mathrm{Bu}_{4} \mathrm{~N}\right)[2 \cdot \mathrm{Br}] \cdot(1 / 6) \mathrm{CH}_{3} \mathrm{C}_{6} \mathrm{H}_{5} \cdot(1 / 2) \mathrm{CH}_{2} \mathrm{Cl}_{2}, \quad\left(\mathrm{Bu}_{4} \mathrm{~N}\right)[3 \cdot \mathrm{Br}] \cdot \mathrm{CH}_{3} \mathrm{C}_{6} \mathrm{H}_{5} \cdot \mathrm{CH}_{2} \mathrm{Cl}_{2} \quad$ and $\left(\mathrm{Bu}_{4} \mathrm{~N}\right)[4 \cdot \mathrm{Br}]$ were collected at $200 \mathrm{~K}$ on an Agilent Supernova diffractometer equipped with an Atlas $\mathrm{CCD}$ detector. ${ }^{38}$ For structures $\left(\mathrm{Bu}_{4} \mathrm{~N}\right)[\mathbf{1} \cdot \mathrm{Cl}],\left(\mathrm{Bu}_{4} \mathrm{~N}\right)[\mathbf{2} \cdot \mathrm{Br}]$ and $\left(\mathrm{Bu}_{4} \mathrm{~N}\right)[3 \cdot \mathrm{Br}] \mathrm{Mo}-\mathrm{K} \alpha$ radiation $(\lambda=0.71073 \AA)$ was used, whereas for structure $(\mathrm{Bu} 4 \mathrm{~N})[4 \cdot \mathrm{Br}], \mathrm{Cu}-\mathrm{K} \alpha$ radiation $(\lambda=1.54180 \AA)$ was employed. No instrument or crystal instabilities were observed during data collection. Absorption corrections based on the multi-scan method were applied. ${ }^{39}$ All structures were solved by charge-flipping methods 
using Superflip ${ }^{40}$ and refined by the least squares method using SHELXL-2013. ${ }^{41}$ Olex2 1.2 software package was used for both the solution and the refinement of the structures. ${ }^{42}$ The crystallographic data collection and structure refinement parameters are given in Table 3.

\section{Insert Table 3}

In all structures, the non-hydrogen atoms were refined anisotropically. Despite some exceptions, the hydrogen atoms bonded to carbon were included at their idealized positions and refined as riders with isotropic displacement parameters assigned as 1.2 times the $\mathrm{U}_{\mathrm{eq}}$ value of the corresponding bonding partner. The structure of $\left(\mathrm{Bu}_{4} \mathrm{~N}\right)[\mathbf{1} \cdot \mathrm{Cl}]$ was refined according to the monoclinic space group P2 $1 / n$. Dichloromethane was found cocrystallized with the cluster complex. Compound $\left(\mathrm{Bu}_{4} \mathrm{~N}\right)[2 \cdot \mathrm{Br}]$ was refined according to the triclinic space group P-1. Dichloromethane and toluene were found cocrystallized with the cluster complex. In the dichloromethane molecule centered at $C(40)$, one chlorine atom was found disordered between two positions and therefore the hydrogen atoms were not included. The sum of the occupation factors of the chlorine atoms was constrained to 1 and their Uij parameters were equated. Structure $\left(\mathrm{Bu}_{4} \mathrm{~N}\right)[3 \cdot \mathrm{Br}]$ was refined according to the monoclinic space group $\mathrm{P} 2{ }_{1}$. Dichloromethane and toluene were also found cocrystallized. In the tetrabutylammonium anion centered at $\mathrm{N}(200)$, one terminal carbon was found to be disordered over two positions. Consequently, their occupation factors were expressed in terms of a "free variable" so that their sum was constrained to 1 and their Uij parameters were equated using the EADP constraint. Owing to disorder, we considered as justified the omission of the hydrogen atoms in this molecule. Finally, the cluster complex $\left(\mathrm{Bu}_{4} \mathrm{~N}\right)[4 \cdot \mathrm{Br}]$ was refined according to the triclinic space group P-1. In the tetrabutylammonium cation, three terminal carbons (C104, C108 
and $\mathrm{C} 112)$ were refined with a partial occupancy $(0.5,0.5$ and 0.75 , respectively). Additionally, the bond distances between three pairs of terminal atoms (C103-C104, C107-C108 and C111-C112) were constrained to a fixed value. The structural figures were drawn by using ORTEP3 v2.02. ${ }^{43}$

Conclusions. In conclusion, novel heteroleptic trinuclear molybdenum cluster complexes containing either mixed diimine-halides or diimine-dithiolene ligands have been prepared and characterized. Their optical power limiting properties have also been investigated and compared to those exhibited by a bis(dithiolene) dinuclear molybdenum cluster prepared formerly by our group, namely $\left(\mathrm{Et}_{4} \mathrm{~N}\right)_{2}\left[\mathrm{Mo}_{2} \mathrm{O}_{2} \mathrm{~S}_{2}\left(\mathrm{BPyDTS}_{2}\right)_{2}\right] .{ }^{13}$ The optical limiting merit increases on increasing metal content, and in most cases it increases when the $\pi$-system is extended by coordination of dmit, an electron-rich ligand. All trinuclear clusters presented herein are optical limiters with $\sigma_{\text {eff }}$ values larger than those of the corresponding ground-state cross-sections $\sigma_{0}$.

Supporting Information. CCDC reference numbers: $1034704\left(\left(\mathrm{Bu}_{4} \mathrm{~N}\right)[\mathbf{1} \cdot \mathrm{Cl}]\right)$, $1034701\left(\left(\mathrm{Bu}_{4} \mathrm{~N}\right)[\mathbf{2} \cdot \mathrm{Br}]\right), 1034702\left(\left(\mathrm{Bu}_{4} \mathrm{~N}\right)[3 \cdot \mathrm{Br}]\right)$ and $1034703\left(\left(\mathrm{Bu}_{4} \mathrm{~N}\right)[\mathbf{4} \cdot \mathrm{Br}]\right)$. These data can be obtained free of charge from The Cambridge Crystallographic Data Centre via www.ccdc.cam.ac.uk/data_request/cif

Acknowledgments. Financial support of the Spanish Ministerio de Economia y Competitividad (MINECO) (Grant CTQ2011-23157), UJI (research project P1.1B201319) and Generalitat Valenciana (Prometeo/2014/022 and ACOMP/2014/274) is gratefully acknowledged. The authors also thank Serveis Centrals d'Instrumentació Cientifica (SCIC), within Universitat Jaume, I for providing them with materials characterization 
facilities. D. R. thanks the Spanish Ministerio de Economía y Competividad for a predoctoral fellowship. M.G.H. thanks the Australian Research Council for support. M.S. acknowledges the NCN grant DEC-2013/10/A/ST4/00114.

\section{References}

$1 \quad$ R. W. Boyd, Nonlinear Optics, Elsevier, 2008.

2 M. G. Humphrey, T. Schwich, P. J. West, M. P. Cifuentes and M. Samoc, in Comprehensive Inorganic Chemistry II, Elsevier, 2013, pp. 781-835.

3 S. Shi, in Optoelectronic Properties of Inorganic Compounds, eds. D. M. Roundhill and J. P. Fackler, Springer US, 1999, p. 412.

4 C. Zhang, Y. Song and X. Wang, Coord. Chem. Rev., 2007, 251, 111-141.

5 S. Shi, W. Ji, J. P. Lang and X. Q. Xin, J. Phys. Chem., 1994, 98, 3570-3572.

6 S. Shi, W. Ji, S. H. Tang, J. P. Lang and X. Q. Xin, J. Am. Chem. Soc., 1994, 116, 3615-3616.

7 J. Li, J. Zhang, M. G. Humphrey and C. Zhang, Eur. J. Inorg. Chem., 2013, 328346.

8 J. M. Garriga, R. Llusar, S. Uriel, C. Vicent, A. J. Usher, N. T. Lucas, M. G. Humphrey and M. Samoc, Dalt. Trans., 2003, 4546-4551.

9 B. J. Coe, J. Fielden, S. P. Foxon, B. S. Brunschwig, I. Asselberghs, K. Clays, A. Samoc and M. Samoc, J. Am. Chem. Soc., 2010, 132, 3496-513.

10 C. C. Frazier, M. A. Harvey, M. P. Cockerham, H. M. Hand, E. A. Chauchard and C. H. Lee, J. Phys. Chem., 1986, 90, 5703-5706.

11 J. Dai, G.-Q. Bian, X. Wang, Q.-F. Xu, M.-Y. Zhou, M. Munakata, M. Maekawa, M.-H. Tong, Z.-R. Sun and H.-P. Zeng, J. Am. Chem. Soc., 2000, 122, 1100711008 .

12 G. Chatzikyriakos, I. Papagiannouli, S. Couris, G. C. Anyfantis and G. C. Papavassiliou, Chem. Phys. Lett., 2011, 513, 229-235.

13 D. Recatalá, A. L. Gushchin, R. Llusar, F. Galindo, K. A. Brylev, M. R. Ryzhikov and N. Kitamura, Dalton Trans., 2013, 42, 12947-55.

14 R. Llusar, S. Uriel, C. Vicent, J. M. Clemente-Juan, E. Coronado, C. J. GomezGarcia, B. Braida and E. Canadell, J. Am. Chem. Soc., 2004, 126, 12076-12083. 
15 R. Llusar, S. Triguero, V. Polo, C. Vicent, C. J. Gómez-García, O. Jeannin and M. Fourmigué, Inorg. Chem., 2008, 47, 9400-9.

R. Llusar and C. Vicent, Coord. Chem. Rev., 2010, 254, 1534-1548.

17 D. Recatalá, R. Llusar, A. L. Gushchin, E. A. Kozlova, Y. A. Laricheva, P. A. Abramov, M. N. Sokolov, R. Gómez and T. Lana-villarreal, ChemSusChem, 2015, 8, 148-157.

18 J. Chen, S. F. Lu, Z. X. Huang, R. M. Yu and Q. J. Wu, Chem. - A Eur. J., 2001, 7, 2002-2006.

19 M. D. Meienberger, K. Hegetschweiler, H. Rüegger and V. Gramlich, Inorganica Chim. Acta, 1993, 213, 157-169.

20 H. Zimmermann, K. Hegetschweiler, T. Keller, V. Gramlich, H. W. Schmalle, W. Petter and W. Schneider, Inorg. Chem., 1991, 30, 4336-4341.

21 M. J. Mayor-López, J. Weber, K. Hegetschweiler, M. D. Meienberger, F. Joho, S. Leoni, R. Nesper, G. J. Reiss, W. Frank, B. A. Kolesov, V. P. Fedin and V. E. Fedorov, Inorg. Chem., 1998, 37, 2633-2644.

22 A. Gushchin, R. Llusar, D. Recatalá and P. Abramov, Russ. J. Coord. Chem., 2012, 38, 173-177.

23 A. V Virovets, A. L. Gushchin, P. A. Abramov, N. I. Alferova, M. N. Sokolov and V. P. Fedin, J. Struct. Chem., 2006, 47, 326-338.

24 M. N. Sokolov, P. A. Abramov, A. L. Gushchin, I. V Kalinina, D. Y. Naumov, A. V Virovets, E. V Peresypkina, C. Vicent, R. Llusar and V. P. Fedin, Inorg. Chem., 2005, 44, 8116-8124.

25 A. L. Gushchin, M. N. Sokolov, E. V. Peresypkina, A. V. Virovets, S. G. Kozlova, N. F. Zakharchuk and V. P. Fedin, Eur. J. Inorg. Chem., 2008, 3964-3969.

26 G. Steimecke, H.-J. Sieler, R. Kirmse and E. Hoyer, Phosphorous Sulfur Relat. Elem., 1979, 7, 49-55.

27 T. K. Hansen, J. Becher, T. Jørgensen, K. S. Varma, Rajesh, M. P. C. Khedekar, J. Hynes and A. B. Smith, Org. Synth., 1996, 73, 270.

28 R. Llusar, S. Uriel, C. Vicent, J. M. Clemente-Juan, E. Coronado, C. J. GómezGarcía, B. Braïda and E. Canadell, J. Am. Chem. Soc., 2004, 126, 12076-12083.

29 R. Llusar, S. Triguero, V. Polo, C. Vicent, C. J. Gómez-García, O. Jeannin and M. Fourmigué, Inorg. Chem., 2008, 47, 9400-9409.

30 A. L. Gushchin, Y. A. Laricheva, P. A. Abramov, A. V. Virovets, C. Vicent, M. N. Sokolov and R. Llusar, Eur. J. Inorg. Chem., 2014, 4093-4100. 
31 A. L. Gushchin, M. N. Sokolov, E. V Peresypkina, A. V Virovets, S. G. Kozlova, N. F. Zakharchuk and V. P. Fedin, Eur. J. Inorg. Chem., 2008, 3964-3969.

32 M. Feliz, J. M. Garriga, R. Llusar, S. Uriel, M. G. Humphrey, N. T. Lucas, M. Samoc and B. Luther-Davies, Inorg. Chem., 2001, 40, 6132-6138.

33 R. L. Sutherland, Handbook of Nonlinear Optics, Marcel Dekker, Inc., 1996.

34 M. Feliz, R. Llusar, S. Uriel, C. Vicent, M. G. Humphrey, N. T. Lucas, M. Samoc and B. Luther-Davies, Inorganica Chim. Acta, 2003, 349, 69-77.

35 M. Schwalbe, B. Schäfer, H. Görls, S. Rau, S. Tschierlei, M. Schmitt, J. Popp, G. Vaughan, W. Henry and J. G. Vos, Eur. J. Inorg. Chem., 2008, 3310-3319.

36 A. Müller, E. Krickemeyer, A. Hadjikyriacou and D. Coucouvanis, in Inorganic Syntheses, ed. A. P. Ginsberg, John Wiley \& Sons, Inc., 1990, vol. 27, pp. 47 - 51.

37 V. P. Fedin, M. N. Sokolov, Y. V. Mironov, B. A. Kolesov, S. V. Tkachev and V. Y. Fedorov, Inorganica Chim. Acta, 1990, 167, 39-45.

38 CrysAllis version 171.35.11.

39 R. H. Blessing, Acta Crystallogr. Sect. A Found. Crystallogr., 1995, 51, 33-38.

40 L. Palatinus and G. Chapuis, J. Appl. Crystallogr., 2007, 40, 786-790.

41 G. M. Sheldrick, Acta Crystallogr. Sect. A, 2008, 64, 112-122.

42 O. V Dolomanov, L. J. Bourhis, R. J. Gildea, J. A. K. Howard and H. Puschmann, J. Appl. Crystallogr., 2009, 42, 339-341.

43 L. J. Farrugia, J. Appl. Crystallogr., 1997, 30, 565.

44 P. Klingelhöfer, U. Müller, C. Friebel and J. Pebler, Zeitschrift für Anorg. und Allg. Chemie, 1986, 543, 22-34.

45 R. Llusar, S. Triguero, S. Uriel, C. Vicent, E. Coronado and C. J. Gomez-Garcia, Inorg. Chem., 2005, 44, 1563-70. 
Table 1. Selected average bond lengths $(\AA)$ for clusters $\left(\mathrm{Bu}_{4} \mathrm{~N}\right)[(\mathbf{1}-\mathbf{4}) \cdot \mathrm{X}]$, together with those of similar complexes $(\mathrm{X}=\mathrm{Cl}$ or $\mathrm{Br})$. Standard deviations are given in parentheses.

\begin{tabular}{cccccccc}
\hline Cluster & Mo-Mo & Mo- $\left(\boldsymbol{\mu}_{3}-\mathbf{S}\right)$ & $\mathbf{M o - S}_{\mathbf{a x}}$ & $\mathbf{M o - S}_{\text {eq }}$ & Mo-N & Mo-X & $\mathbf{S}_{\mathbf{a x}} \cdots \mathbf{X}$ \\
\hline$\left(\mathrm{Et}_{4} \mathrm{~N}\right)_{3}\left[\mathrm{Mo}_{3} \mathrm{~S}_{7} \mathrm{Cl}_{6}\right]^{44}$ & $2.758(2)$ & $2.346(3)$ & $2.391(3)$ & $2.483(3)$ & - & $2.478(3)$ & $2.94(7)$ \\
$(\mathrm{ET})_{3}\left[\mathrm{Mo}_{3} \mathrm{~S}_{7} \mathrm{Br}_{6}\right]^{45}$ & $2.737(3)$ & $2.344(6)$ & $2.384(7)$ & $2.466(7)$ & - & $2.610(4)$ & $3.05(2)$ \\
$\left(\mathrm{Bu}{ }_{4} \mathrm{~N}\right)[\mathbf{1} \cdot \mathrm{Cl}]$ & $2.7502(6)$ & $2.3531(12)$ & $2.3852(13)$ & $2.4861(14)$ & $2.211(4)$ & $2.4644(13)$ & $2.93(4)$ \\
$\left(\mathrm{Bu}_{4} \mathrm{~N}\right)[\mathbf{2} \cdot \mathrm{Br}]$ & $2.7502(11)$ & $2.359(3)$ & $2.393(3)$ & $2.481(3)$ & $2.211(8)$ & $2.6172(14)$ & $3.05(5)$ \\
$(\mathrm{Bu} 4 \mathrm{~N})[\mathbf{3} \cdot \mathrm{Br}]$ & $2.7438(14)$ & $2.3583(3)$ & $2.391(3)$ & $2.485(3)$ & $2.225(10)$ & $2.6212(17)$ & $3.043(14)$ \\
$(\mathrm{Bu} 4 \mathrm{~N})[\mathbf{4} \cdot \mathrm{Br}]$ & $2.7414(7)$ & $2.3553(15)$ & $2.3958(16)$ & $2.4852(17)$ & $2.216(5)$ & $2.6083(9)$ & $3.04(8)$ \\
\hline
\end{tabular}

$\mathrm{dtc}=$ diethyldithiocarbamate; $\mathrm{ET}=$ bis(ethylendithio)tetrathiafulvalene 
Table 2. Linear Optical and Optical-Limiting Data for $\left(\mathrm{Et}_{4} \mathrm{~N}\right)_{2}\left[\mathrm{Mo}_{2} \mathrm{O}_{2} \mathrm{~S}_{2}\left(\mathrm{BPyDTS}_{2}\right)_{2}\right]^{13}$ and complexes $\mathbf{1}-\mathbf{7}$.

\begin{tabular}{|c|c|c|c|c|c|c|c|c|}
\hline \multirow[b]{2}{*}{ cluster } & \multicolumn{6}{|c|}{ Optical abs $\lambda, \mathrm{nm}\left(\varepsilon, 10^{3} \mathrm{dm}^{3} \mathrm{~mol}^{-1} \mathrm{~cm}^{-1}\right)$} & \multicolumn{2}{|c|}{ Cross section $\left(10^{-18} \mathrm{~cm}^{2}\right)$} \\
\hline & $\lambda_{1}\left(\varepsilon_{1}\right)$ & $\lambda_{2}\left(\varepsilon_{2}\right)$ & $\lambda_{3}\left(\varepsilon_{3}\right)$ & $\begin{array}{c}\text { Conc. }\left(10^{-4}\right. \\
\left.\mathrm{mol} \mathrm{L}^{-1}\right)\end{array}$ & $\lambda_{\mathrm{m}}\left(\varepsilon_{\mathrm{m}}\right)^{a}$ & $F_{15 \%}\left(\mathrm{~J} \mathrm{~cm}^{-2}\right)^{b}$ & $\begin{array}{l}\text { Ground state, } \\
\sigma_{0}\end{array}$ & Excited state, $\sigma_{\text {eff }}$ \\
\hline Ref. [13] & $341(32)$ & $423(\mathrm{sh}, 10.1)$ & $525(2.4)$ & 27.2 & $570(1590)$ & 0.32 & 6.1 & 5.5 \\
\hline 1 & $320(\mathrm{sh}, 11.1)$ & $370(\mathrm{sh}, 5.3)$ & $450(2.3)$ & 9.6 & $570(310)$ & 0.25 & 1.2 & 2.1 \\
\hline 2 & $313(\mathrm{sh}, 21.1)$ & $375(\mathrm{sh}, 7.5)$ & $461(3.7)$ & 7.8 & $570(830)$ & 0.14 & 3.2 & 3.4 \\
\hline 3 & $313(\mathrm{sh}, 16.5)$ & $370(\mathrm{sh}, 5.2)$ & $471(\mathrm{sh}, 2.4)$ & 7.1 & $570(790)$ & 0.13 & 3.0 & 3.2 \\
\hline 4 & $304(\mathrm{sh}, 14.9)$ & $352(\mathrm{sh}, 6.1)$ & 493 (sh, 1.9 & 7.2 & $570(820)$ & 0.20 & 3.2 & 3.9 \\
\hline 5 & $307(\mathrm{sh}, 27.7)$ & - & 497 (16.1) & 3.2 & $570(4410)$ & 0.19 & 16.9 & 21.3 \\
\hline 6 & $332(\mathrm{sh}, 17.1)$ & $407(\mathrm{sh}, 7.4)$ & 493 (10.2) & 3.8 & $500(9920)$ & 0.31 & 37.9 & 37.0 \\
\hline & & & & & $532(6330)$ & 0.30 & 24.2 & 23.4 \\
\hline & & & & & $570(3540)$ & 0.22 & 13.5 & 15.3 \\
\hline & & & & & $640(1560)$ & 0.19 & 5.9 & 9.3 \\
\hline 7 & $311(\mathrm{sh}, 24.8)$ & $335(\mathrm{sh}, 17)$ & $500(9.7)$ & 5.5 & $570(3060)$ & 0.20 & 11.7 & 12.7 \\
\hline
\end{tabular}

${ }^{a}$ Measurement wavelength in $\mathrm{nm}$ (extinction coefficient at the measurement wavelength in $\mathrm{dm}^{3} \mathrm{~mol}^{-1} \mathrm{~cm}^{-1}$ ). ${ }^{b} F_{15 \%}$ is defined as the incident fluence needed to reduce the transmittance through the sample by $15 \%$. 
Table 3. Crystallographic data for $\left(\mathrm{Bu}_{4} \mathrm{~N}\right)[\mathbf{1} \cdot \mathrm{Cl}] \cdot 3 \mathrm{CH}_{2} \mathrm{Cl}_{2}$, $\left(\mathrm{Bu}_{4} \mathrm{~N}\right)[2 \cdot \mathrm{Br}] \cdot(1 / 6) \mathrm{CH}_{3} \mathrm{C}_{6} \mathrm{H}_{5} \cdot(1 / 2) \mathrm{CH}_{2} \mathrm{Cl}_{2}, \quad\left(\mathrm{Bu}_{4} \mathrm{~N}\right)[3 \cdot \mathrm{Br}] \cdot \mathrm{CH}_{3} \mathrm{C}_{6} \mathrm{H}_{5} \cdot \mathrm{CH}_{2} \mathrm{Cl}_{2} \quad$ and $(\mathrm{Bu} 4 \mathrm{~N})[4 \cdot \mathrm{Br}]$

\begin{tabular}{|c|c|c|c|c|}
\hline Compound & $\left(\mathrm{Bu}_{4} \mathrm{~N}\right)[\mathbf{1} \cdot \mathrm{Cl}] \cdot \mathrm{Solv}$ & $\left(\mathrm{Bu}_{4} \mathrm{~N}\right)[2 \cdot \mathrm{Br}] \cdot \mathrm{Solv}$ & $\left(\mathrm{Bu}_{4} \mathrm{~N}\right)[3 \cdot \mathrm{Br}] \cdot \mathrm{Solv}$ & $\left(\mathrm{Bu}_{4} \mathrm{~N}\right)[4 \cdot \mathrm{Br}]$ \\
\hline Empirical formula & $\mathrm{C}_{31} \mathrm{H}_{53} \mathrm{Cl}_{11} \mathrm{Mo}_{3} \mathrm{~N}_{3} \mathrm{~S}_{7}$ & $\mathrm{C}_{29.7} \mathrm{H}_{50} \mathrm{Br}_{5} \mathrm{ClMo}_{3} \mathrm{~N}_{3} \mathrm{~S}_{7}$ & $\mathrm{C}_{30} \mathrm{H}_{30.5} \mathrm{Br}_{5} \mathrm{ClMo}_{3} \mathrm{~N}_{3} \mathrm{~S}_{7}$ & $\mathrm{C}_{26.75} \mathrm{H}_{36.25} \mathrm{Br}_{5} \mathrm{Mo}_{3} \mathrm{~N}_{3} \mathrm{~S}_{7}$ \\
\hline Formula weight & 1369.95 & 1395.96 & 1380.31 & 1311.63 \\
\hline Crystal system & Monoclinic & Triclinic & Monoclinic & Triclinic \\
\hline$a, \AA$ & $13.8174(2)$ & $19.3605(3)$ & $11.19024(19)$ & $11.9690(3)$ \\
\hline$b, \AA$ & $19.3711(3)$ & $25.9644(4)$ & $32.5907(6)$ & $12.7039(4)$ \\
\hline$c, \AA$ & $20.0877(3)$ & $34.7600(5)$ & $14.5892(3)$ & $16.6526(5)$ \\
\hline$\alpha^{\mathrm{o}}$ & 90 & $71.8853(15)$ & 90 & $71.325(3)$ \\
\hline$\beta^{\text {o }}$ & $103.4323(15)$ & 76.3237(14) & $108.499(2)$ & $79.119(2)$ \\
\hline$\gamma^{\circ}$ & 90 & 76.3237(14) & 90 & $65.163(3)$ \\
\hline$V, \AA^{3}$ & $5229.55(14)$ & $15442.7(5)$ & $5045.73(16)$ & $2172.55(12)$ \\
\hline$T, \mathrm{~K}$ & 200 & 200 & 200 & 200 \\
\hline Space group & $\mathrm{P} 2_{1} / \mathrm{n}$ & $\mathrm{P}-1$ & $\mathrm{P} 2_{1}$ & $\mathrm{P}-1$ \\
\hline$Z$ & 4 & 2 & 2 & 2 \\
\hline$\mu(\mathrm{Mo} \mathrm{K} \alpha), \mathrm{mm}^{-1}$ & 1.578 & 4.960 & 5.060 & - \\
\hline$\mu(\mathrm{Cu} \mathrm{K \alpha}), \mathrm{mm}^{-1}$ & - & - & - & 15.699 \\
\hline Reflections collected & 50572 & 331374 & 48304 & 31156 \\
\hline Unique reflections & 9195 & 60352 & 17681 & 8395 \\
\hline$R_{\text {int }}$ & 0.0332 & 0.0725 & 0.0338 & 0.0712 \\
\hline Goodness-of-fit on $F^{2}$ & 1.088 & 1.035 & 1.068 & 1.027 \\
\hline$R 1^{[\mathrm{a}]} / w R 2^{[\mathrm{b}]}$ & $0.0426 / 0.1056$ & $0.0645 / 0.1673$ & $0.0429 / 0.1225$ & $0.0538 / 0.1534$ \\
\hline$R 1^{[\mathrm{a}]} / w R 2^{[\mathrm{b}]}$ (all data) & $0.0541 / 0.1188$ & $0.1150 / 0.2007$ & $0.0470 / 0.1256$ & $0.0612 / 0.1654$ \\
\hline $\begin{array}{l}\text { Max/Min residual } \rho \\
\text { /e. } \mathrm{A}^{-3}\end{array}$ & $1.54 /-0.90$ & $3.08 /-1.08$ & $3.29 /-0.58$ & $1.75 /-1.46$ \\
\hline
\end{tabular}

[a] $R 1=\sum|| F_{0}|-| F_{1}|| / \sum F_{0} ;[\mathrm{b}] w R 2=\left[\sum\left[w\left(F_{0}^{2}-F_{c}^{2}\right)^{2}\right] / \sum\left[w\left(F_{0}^{2}\right) 2\right]\right]^{1 / 2}$ 